\title{
Improving Learning Outcomes through Learning Media in Making Financial Reports at the Hospitality Board
}

\author{
Ni Luh Gede Erni Sulindawati ${ }^{*}$ \\ ${ }^{1}$ Economics and Accounting Department, Universitas Pendidikan Ganesha, Singaraja, Indonesia
}

\section{A R T I CLE IN F O}

Article history:

Received May 31, 2021

Revised June 03, 2021

Accepted October 20, 2021

Available online November 25, 2021

\section{Kata Kunci :}

Media Pembelajaran, Laporan

Keuangan, Perhotelan Entitas,

Hasil Pembelajaran

Keywords:

Learning Media, Financial Report, Hospitality Entities, Learning Outcomes



This is an open access article under the $\underline{C C}$ BY-SA license.

Copyright (C) 2021 by Author. Published by Universitas Pendidikan Ganesha

\begin{abstract}
A B S T R A K
Belum memadainya media pembelajaran yang digunakan dalam pembelajaran akuntansi perhotelan, sehingga berdampak pada sulitnya siswa memahami materi pembelajaran. Penelitian ini bertujuan untuk menguji efektivitas media pembelajaran dalam pembuatan laporan keuangan perhotelan melalui aplikasi spreadsheet. Desain penelitian dalam kegiatan ini akan menggunakan pengembangan perangkat pembelajaran menurut Sugiono. Metode penelitian ini menggunakan model pengembangan media pembelajaran yang meliputi langkahlangkah yaitu pengujian produk, revisi produk, dan uji coba penggunaan. Subyek penelitian adalah mahasiswa program studi akuntansi perhotelan. Instrumen yang digunakan terdiri dari pedoman observasi, pedoman wawancara, angket, dan tes hasil belajar. Peserta uji coba produk berjumlah 15 orang mahasiswa pemograman mata kuliah akuntansi perhotelan dan uji coba penggunaan sebanyak 34 orang dalam 1 kelas. Teknik analisis data yang digunakan dalam penelitian ini adalah deskriptif dengan mengukur hasil tes belajar siswa dilihat dari skor yang diperoleh siswa dalam proses pembelajaran penyusunan laporan keuangan entitas perhotelan. Penilaian dilakukan berdasarkan skor yang diperoleh dari hasil belajar penilaian proses sikap dan partisipasi, dan pemberian tugas, serta penilaian terhadap produk yang dihasilkan. Hasil evaluasi penggunaan media pembelajaran dalam pembuatan laporan keuangan melalui aplikasi spreadsheet diketahui hasil belajar siswa sangat baik sehingga media ini memenuhi syarat efektifitas suatu media pembelajaran, sehingga media ini dapat digunakan dalam pembelajaran akuntansi perhotelan.
\end{abstract}

\begin{abstract}
A B S T R A C T
Inadequate learning media used in hospitality accounting learning has an impact on the difficulty of understanding the learning material. This study examines the effectiveness of learning media in making hospitality financial reports through a spreadsheet application. The research design in this activity will use the development of learning tools, according to Sugiono. This research method uses a learning media development model which includes steps, namely product testing, product revision, and uses trials. The research subjects were students of the hospitality accounting study program. The instrument used consisted of observation guidelines, interviews, questionnaires, and learning outcomes tests. The participants of the product trial were 15 students of programming courses in hospitality accounting, and 34 people in one class were tested for use. The data analysis technique used in this research is descriptive by measuring the results of student learning tests seen from the scores obtained by students in learning the financial statements of hospitality companies. The assessment is carried out based on the scores obtained from the learning outcomes of attitude and participation assessment, assignment of assignments, and an assessment of the resulting product. The results of the evaluation of the use of media in making financial reports through spreadsheets show that student learning outcomes are excellent so that this media meets the requirements for the effectiveness of media learning so that this media can be used in educational accounting learning.
\end{abstract}

\section{INTRODUCTION}

This research is motivated by the inadequate learning media used in hospitality accounting learning (Sulindawati, 2021). In today's era, students are expected to have expertise in using technology (Burik, 2021; Fu \& Hwang, 2018; Molin et al., 2020). Technology is required in all areas of competence (Aini et al., 2020; Bastemur \& Bastemur, 2015; Sert \& Boynueğri, 2017). One of the competencies expected from accounting graduates is the ability to compile financial reports from various entities, both service companies, trade, industry, both those engaged in government and the hotel industry (Andon et al., 2010; Nagle et al., 2018). From the observations it has been made on students who program hospitality accounting courses are still having difficulty in compiling hotel financial reports. With these problems the authors are interested in developing a learning media using a spreadsheet program (Djannah et al., 2021; Saripudin et 
al., 2018). To be able to improve the competency or ability of students in the practice of making financial statements of hospitality entities, learning media are needed that can facilitate student understanding. The media that can be used to facilitate the preparation of financial statements for hospitality entities is a spreadsheet application. Spreadsheet application can make it easier for students to understand the making financial statements steps of hospitality entities by utilizing the sheets in the application (Man \& Strandhagen, 2018; Sulindawati, 2021).

This article is a continuation of the previous article about development media analysis in financial statements learning practices of hospitality entities through spreadsheet, which explains that there is a lack of students understanding in compiling financial reports for hospitality entities, so learning media is developed through spreadsheet applications, the media that has been developed after analyzing the results of validity and reliability tests, it is known that the learning media developed are valid and reliable, and because the results are valid and reliable, so that the next step the developed media needs to be tested and implemented in the learning process (Sulindawati, 2021). Learning media developed after being assessed by experts need to be tested (Adha, 2012; Sulindawati, 2021). Based on this, the media developed in the preparation of this hospitality financial report will be tested to test the effectiveness of the application of the developed learning media. Effectiveness can be measured by user perceptions and learning outcomes obtained by students after using learning media. The existence of learning media as a tool in learning activities is an undeniable fact, without media, learning material will be difficult to digest and understand by students, if the learning material that must be delivered is complex, so the use of media is absolutely necessary. conducted so that the subject matter can reach students effectively and efficiently (Mahnun, 2012; Muhson, 2010; Tafonao, 2018).

The benefits of media in the educational process are improving quality and the quality of education by increasing the speed of activity, giving a more individualized educational probability, providing the basis for more scientific learning activities (Prasetyo et al., 2020; Puspitarini \& Hanif, 2019; Saripudin et al., 2018). Learning activities can be carried out steadily, increasing the realization of learning closeness, and provide a broader educational presentation (Harahap \& Siregar, 2018; Mahnun, 2012; Muhson, 2010). In order for the media to be used effectively and efficiently, several principles are needed. Regarding the increasing diversity of learning media, the choice of media should pay attention to three principles, including purpose of clarity and media selection, whether for purposes, entertainment, general information, learning and so on, media familiarity, which involves knowledge of the nature and characteristics of the media to be used, and the number of media can be compared through the selection of several media that are more suitable for learning objectives (Mahnun, 2012; Muhson, 2010; Tafonao, 2018). Learning media has an important role, the role of learning media in the learning and teaching process is an integral and inseparable part of the world of education (Rahayu et al., 2021; Tafqihan, 2011). Learning media is anything that can be used to transmit messages from the sender to the recipient, so as to stimulate thoughts, feelings, attention, and students' interest in learning on the media category (Harahap \& Siregar, 2018; Mahnun, 2012; Muhson, 2010; Setyowati et al., 2018; Tafonao, 2018; Yasdar et al., 2019).

There are six categories of media, namely unprojected media, projected media, audio media, film and video media, multimedia, and communication-based media (Harahap \& Siregar, 2018; Lestari et al., 2020; Mahnun, 2012; Muhson, 2010; Tafonao, 2018). The general characteristics of learning media are learning media is identical to the meaning of demonstration which comes from the word "raga", meaning an object that can be felt, seen and heard and which can be observed through the five senses, the main stress lies in objects or things that can be seen and heard (Pratiwi et al., 2016; Puspitarini \& Hanif, 2019). Learning media are used in the context of relationships (communication) in teaching between teachers and students. Learning media is a kind of teaching and learning aid , both inside and outside the classroom (Prasetyo et al., 2020; Puspitarini \& Hanif, 2019). One of the media that can be used in learning is the Microsoft Excel application or Spreadsheet Excel is a spreadsheet program in the Microsoft Office system (Man \& Strandhagen, 2018; Satria \& Fatmawati, 2021). People can use Excel to create and format workbooks to analyze data and create data itself. Specifically, can use Excel to track data, build models to analyze data, write formulas to do calculations on that data, process data in various ways, and present data in various graphs. Application of the spreadsheet can facilitate the preparation of financial reports. When compiling a report, it is necessary to prepare a financial statement from the list of transactions.

The main product of this research is learning media in the practice of making financial reports in hospitality entities through spreadsheet applications. With the availability of this research product, it is hoped that it will be able to contribute in completing the learning media needed in lectures in the accounting study program. The products that will be produced can add learning media about the combination of the development of accounting science based on real problems in the hospitality industry with the rapid development of technology, especially computer technology. This study aims to examine the effectiveness of instructional media in making hospitality financial reports through a spreadsheet application. The 
existence of this research product will also be able to create a pleasant learning atmosphere and conditions by bringing the situation closer to the real conditions that occur in the hospitality industry so that students' creative and practical thinking skills can be improved.

\section{METHODS}

The research design in this activity will use the development of learning tools according to Sugiono (Sugiyono, 2013). This research uses the development method at the limited trial stage, and the assessment of the learning process to determine student competence. The trial subjects are limited to 15 people. Trial of learning media in the practice of making financial statements in hospitality entities through the spreadsheet application in small groups and evaluating the learning outcomes of lecture participants by providing practical tests for making financial reports on hotel entities. The first step is to develop learning media in the practice of making financial reports on hotel entities through spreadsheet applications. Furthermore, the revision of the development of learning media for the practice of making financial reports through a spreadsheet application. The subjects in this study are students who program hospitality accounting courses. The data collection instruments used consisted of several instruments, namely: Observation guidelines, questionnaires, interview guidelines, and documentation studies (Nawantara et al., 2020).

The data analysis technique used in this study was to follow the qualitative and quantitative data analysis procedures by analyzing the results of student learning tests. The criteria for the assessment of the learning outcomes test follow the guideline values set in the Undiksha assessment guidebook. 0-39 40-60 61-64 65-68 69-72 77-80 81-84 85-100 (Undiksha, 2017). Analysis of Learning Outcomes, Assessment Process Attitudes and Participation, Results of Assessment Process Assignments, Product Assessment MidTerm Exam. And assessment of student UAS products is carried out "through calculations with the formula: Percentage of value of learning process results (PPS) = score obtained divided by the maximum score $\mathrm{x}$ $100 \%$ Furthermore, the percentage value is categorized based on the following provisions: high (76-100\%), moderate (56-75\%), poor (40-55\%), and poor (<40\%) (Fatmawati, 2016).

\section{RESULT AND DISCUSSION}

\section{Results}

Learning media in the practice of making hotel financial reports through a spreadsheet application containing accounting cycles by utilizing existing sheets. As an illustration, it can be made on the first sheet of the journal, the second sheet and so on the ledger according to the accounts in the asset, passive, income and expense groups, the next sheet can be made a trial balance, adjusting journal entries, work sheet, and financial statements. namely income statement, statement of changes in equity and balance sheet. The steps in the practice of making financial statements include analyzing evidence of transactions, making journals, posting journals to ledgers, compiling trial balances from balances in the ledgers, make an adjusting journal, make a work sheet or working paper, prepare a financial report: consisting of an income statement, a statement of changes in equity and a final balance sheet, making a closing journal, and preparing a trial balance after closure and analysis of hospitality financial statements. The steps for preparing these financial statements can be made through the Spreadsheet program or Microsoft Excel program as illustrated in the following.

After the transaction analysis is carried out, a journal book containing the Debit and Credit columns is made, while transactions that are always recurring are usually not recorded in the Debit Credit journal, but are recorded in a special journal with columns. A journal like this is specifically designed for recording certain transactions by taking into account the accounts that must be debited and credited. This method will reduce the work of keeping a journal and will make it easier to keep accounts. For transactions that do not occur frequently and are internal transactions, a general journal is made with debit and credit columns. Special journals are usually made in pairs for transactions that often occur such as sales and money receipts journals, money purchases and expenditure journals and others. To make a journal, you can use the Spreadsheet program or the Microsoft Excel program. In this program, columns for Date, Description, Ref, Credit Debit are made. The date column is filled with the date when the transaction occurred, the description column is filled with the account name or estimate, the ref column is filled in after the account is posted to the ledger, the debit and credit columns are filled with the amount of rupiah in accordance with the debit and credit rules for an account.

Product trials were conducted on 15 students who program hospitality accounting courses. In the results of product testing, student responses are positive and have the view that the procedures and steps for preparing financial reports are easier using a spread sheet application. The next step is to test product 
usage. The usage test was carried out on one class of 34 students. At the beginning of the lecture, the lecturer submits a plan for lecture activities and informs about the supporting tools consisting of syllabus for hospitality accounting courses, semester learning plans, and lecture contracts, a collection of cases related to entities hospitality. During the initial lecture meeting, discussions were also held with students regarding the lecture contract and discussing the expected course learning outcomes, namely being able to compile financial reports of a hotel entity. To facilitate students' understanding in preparing the financial statements of hospitality entities through this spreadsheet, students are guided in the learning process by providing systematic steps in preparing the financial statements of a hotel entity. These steps are identifying evidence of transactions, making a general journal, posting the journal to the ledger, compiling a trial balance in the ledger, making an adjusting journal, making a work sheet or working paper, preparing a financial report: consisting of an income statement, a report on changes in equity and a final balance sheet, making a closing journal, preparing a balance sheet balance after closing and hotel financial statement analysis.

Assessments for student learning activities are grouped based on the steps for preparing financial statements Identifying transaction evidence, making journals, posting journals to ledgers, compiling trial balances from the balances in ledgers, making adjusting journals, making work sheet or working paper, preparing financial statements: consisting of an income statement, a statement of changes in equity and a final balance sheet, making a closing journal, prepare a trial balance after closing and analyze financial statements for hotels. The assessment carried out in lectures is related to the assessment process, namely attitudes and participation, assignments, and resulting product assessment. Based on the results of data analysis, the average score of student attitudes and participation, which is obtained is in the range of $18 \%$ (77$80), 18 \%(81-84)$ and $64 \%$ (85-100) which are classified as very good. The average process assessment score of assignments given by students, which is obtained is in the range of $18 \%$ (77-80), 20\% (81-84) and 62\% (85100 ) which are classified as $20 \%$. good category and $62 \%$ very good. The average score of student product assessments obtained is in the range of $15 \%$ (77-80), 18\% (81-84) and 67\% (85-100) which are classified as $18 \%$ good and $67 \%$ very good category. From the results of assessments carried out in lectures related to process assessments, namely attitudes and participation, assignments, and product assessments, the results show that the level of mastery and understanding of the students is good. The results showed that the Learning Media in the practice of making hotel financial reports through the spreadsheet application can be used as a learning resource and can be used as a learning medium in hospitality accounting courses. With the results of this evaluation, it can ultimately improve student competence in making financial reports of hospitality entities.

\section{Discussion}

The development of learning media in compiling financial reports using this spreadsheet application is an alternative solution that can be used in compiling financial reports for hospitality entities. Students will understand how to prepare financial reports better because of systematic procedures. Computer-based learning is one of the learning media that utilizes all computer capabilities, consisting of a combination of almost all media, namely: text, graphics, and images so that it is very interesting and able to increase students' learning motivation (Ottenbreit-Leftwich et al., 2021; Wu et al., 2021). The right learning media can help play an active role in learning activities, make it easier for students to understand material, and encourage the spirit of learning with interest in participating in learning (Ningsih \& Gustimalasari, 2018; Silaban \& Rizal, 2020; Widiana \& Rendra, 2020). The high learning motivation of students leads to an increase in learning outcomes (Puspitarini \& Hanif, 2019; Saripudin et al., 2018; Sudjimat \& Luchyto, 2019).

In addition, with this learning media, students can immediately practice how to prepare financial reports. Learning is seen as a trying to understand something (Anitha Kumari et al., 2020; Hosen et al., 2021; Lauc et al., 2020). The effort was actively carried out by students. This activity can be in the form of seeking experience, seeking information, solving problems, observing environment, practicing something to achieve a certain goal. Based on cognitive psychology, learning outcomes will be able to increase if students can directly practice the material being studied (Geng et al., 2019; Jamaludin et al., 2020; Putra, 2021). The quality of a product can be measured from user responses. Users in this study were students, from the results of interviews and questionnaire tabulations, it was known that student responses were very positive and also had the same view as students during product trials. Students' views when testing the use of preparing financial reports through spreadsheets are easy to use because in making financial reports following the instructions given starting from the first sheet of journal compilation, using the next sheet formula, financial reports will be automatically presented. Interestingly, a media for students will cause students to play an active role in learning. This statement is in accordance with the opinion (Huda et al., 2019; Widiana \& Rendra, 2020).

The results of this study are in line with the results of research who concluded that students as participants were able to accept the spreadsheet method as a method that could assist participants in preparing financial statements in the accounting cycle. The other research concluded that the spreadsheet application can be used as an alternative for processing financial reports for small and medium-sized 
companies (Man \& Strandhagen, 2018; Satria \& Fatmawati, 2021). From the results obtained from this study, it can strengthen the theory that effective learning media can increase students' interest in learning and learning outcomes. With this learning media product, it can add learning media about the combination of the development of accounting science based on real problems in the hotel industry with the rapid development of computer technology. The existence of this research product will also be able to create a pleasant learning atmosphere and conditions by bringing the situation closer to the real conditions that occur in the hospitality industry so that students' creative and practical thinking skills can be improved.

\section{CONCLUSION}

The application of learning media in making financial reports with spreadsheet applications is known that student learning outcomes from the value of the process of attitude and participation, assignments and product values obtained scores are classified as very good so that this media can be used in hospitality accounting learning. From student responses, it can be seen that students can understand the preparation of financial reports with spreadsheets and want to always use this application in making financial reports. From the results of product trials and trials of using learning media, the application of the conditions is practical because the application of learning media has met the learning outcomes and created a new atmosphere in the learning environment.

\section{REFERENCES}

Adha, M. M. (2012). Model Pengembangan Pembelajaran Pendididikan Kewarganegaraan Berbasis Multikultur Dalam Rangka Menanamkan Nilai-Nilai HAM dan Demokrasi. Jurnal Media Komunikasi FIS, 12, 1-16. https://doi.org/10.23887/mkfis.v12i2.1705.

Aini, Q., Rahardja, U., Tangkaw, M. R., Santoso, N. P. L., \& Khoirunisa, A. (2020). Embedding a Blockchain Technology Pattern Into the QR Code for an Authentication Certificate. Jurnal Online Informatika, 5(2). https://doi.org/10.15575/join.v5i2.583.

Andon, P., Chong, K. M., \& Roebuck, P. (2010). Personality preferences of accounting and non-accounting graduates seeking to enter the accounting profession. Critical Perspectives on Accounting, 21(4). https://doi.org/10.1016/j.cpa.2010.01.001.

Anitha Kumari, T., Hemalatha, C. H., Subhani Ali, M., \& Naresh, R. (2020). Survey on impact and learning's of the online courses on the present era. Procedia Computer Science, 172, 82-91. https://doi.org/10.1016/j.procs.2020.05.167.

Bastemur, S., \& Bastemur, E. (2015). Technology Based Counseling: Perspectives of Turkish Counselors. Procedia - Social and Behavioral Sciences, 176(1998), 431-438. https://doi.org/10.1016/j.sbspro.2015.01.493.

Burik, A. (2021). Using Technology to Help Students Set, Achieve, and Publicize Goals. Adult Literacy Education: The International Journal of Literacy, Language, and Numeracy, 3(1), 83-89. https: //doi.org/10.35847/aburik.3.1.83.

Djannah, M., Zulherman, Z., \& Nurafni. (2021). Kahoot Application for Elementary School Students: Implementations of Learning Process from Distance during Pandemic period of COVID 19. Journal of Physics: Conference Series, 1783(1), 012121. https://doi.org/10.1088/17426596/1783/1/012121.

Fatmawati, A. (2016). Pengembangan Perangkat Pembelajaran Konsep Pencemaran Lingkungan Menggunakan Model Pembelajaran Berdasarkan Masalah Untuk Sma Kelas X. EduSains, 4(2), 10. https://doi.org/10.23971/eds.v4i2.512.

Fu, Q. K., \& Hwang, G. J. (2018). Trends in mobile technology-supported collaborative learning: A systematic review of journal publications from 2007 to 2016. Computers and Education, 119(July 2017), 129143. https://doi.org/10.1016/j.compedu.2018.01.004.

Geng, S., Law, K. M. Y., \& Niu, B. (2019). Investigating self-directed learning and technology readiness in blending learning environment. International Journal of Educational Technology in Higher Education, 16(1), 17. https://doi.org/10.1186/s41239-019-0147-0.

Harahap, M., \& Siregar, L. M. (2018). Mengembangkan sumber dan media pembelajaran. Educational, January, 10. https://doi.org/10.13140/RG.2.2.19282.86721.

Hosen, M., Ogbeibu, S., Giridharan, B., Cham, T.-H., Lim, W. M., \& Paul, J. (2021). Individual motivation and social media influence on student knowledge sharing and learning performance: Evidence from an emerging economy. $\quad$ Computers Education, 172. https://doi.org/10.1016/j.compedu.2021.104262. 
Huda, A. K., Reffiane, F., \& Untari, M. F. asri. (2019). Keefektifan Model Pembelajaran Tebak Kata Terhadap Hasil Belajar Ipa Siswa Kelas III SD Negeri Rejosari 03 Kota Semarang. Malih Peddas (Majalah Ilmiah Pendidikan Dasar), 8(2), 171. https://doi.org/10.26877/malihpeddas.v8i2.3072.

Jamaludin, G. M., Supriatna, D., \& Burhani, A. Z. (2020). the Effect of Online Learning System During the Covid-19 Pandemic on Students' Learning Motivation and Interest in Learning. Jurnal Tatsqif, 18(2), 169-182. https://doi.org/10.20414/jtq.v18i2.2795.

Lauc, T., Jagodić, G. K., \& Bistrović, J. (2020). Effects of Multimedia Instructional Message on Motivation and Academic Performance of Elementary School Students in Croatia. International Journal of Instruction, 13(4), 491-508. https://doi.org/10.29333/iji.2020.13431a.

Lestari, M. Y. W., Musarokah, S., \& Prashanty, A. D. (2020). Using Technology in English Teaching of PreService Teachers in 4.0 Industrial Revolution Era. ETERNAL (English Teaching Journal), 11(1), 7581. https://doi.org/10.26877/eternal.v11i1.6072.

Mahnun, N. (2012). Media Pembelajaran (Kajian terhadap Langkah-langkah Pemilihan Media dan Implementasinya dalam Pembelajaran). An-Nida', 37(1), 27-35. https://doi.org/10.24014/annida.v37i1.310.

Man, J. C. de, \& Strandhagen, J. O. (2018). Spreadsheet Application still dominates Enterprise Resource Planning and Advanced Planning Systems. IFAC-PapersOnLine, 51(11). https://doi.org/10.1016/j.ifacol.2018.08.423.

Molin, F., Haelermans, C., Cabus, S., \& Groot, W. (2020). Do feedback strategies improve students' learning gain?-Results of a randomized experiment using polling technology in physics classrooms. Computers \& Education, 175. https://doi.org/10.1016/j.compedu.2021.104339.

Muhson, A. (2010). Pengembangan Media Pembelajaran Berbasis Teknologi Informasi. Jurnal Pendidikan Akuntansi Indonesia, 8(2), 2. https://doi.org/https://doi.org/10.21831/jpai.v8i2.949.

Nagle, B. M., Menk, K. B., \& Rau, S. E. (2018). Which accounting program characteristics contribute to CPA exam success? A study of institutional factors and graduate education. Journal of Accounting Education, 45. https://doi.org/10.1016/j.jaccedu.2018.09.003.

Nawantara, R. D., Arofah, L., \& Setyaputri, N. Y. (2020). Self-Instruction Technical Guidelines to Improve High School Students's Self-Discipline. 387(Icei), 361-365. https://doi.org/10.2991/icei-19.2019.86.

Ningsih, S. Y., \& Gustimalasari, G. (2018). Penggunaan Strategi Pembelajaran Aktif Everyone Is a Teacher Here (Eth) Terhadap Kemampuan Pemahaman Konsep Matematika Siswa Kelas Vii. MES: Journal of Mathematics Education and Science, 4(1), 95-100. https://doi.org/10.30743/mes.v4i1.876.

Ottenbreit-Leftwich, A. T., Kwon, K., Brush, T. A., Karlin, M., Jeon, M., Jantaraweragul, K., \& Guo, M. (2021). The impact of an issue-centered problem-based learning curriculum on 6th grade girls' understanding of and interest in computer science. Computers and Education Open, 2. https://doi.org/10.1016/j.caeo.2021.100057.

Prasetyo, G., Hidayatullah, M. F., Akhyar, M., Wiranto, \& Perdana, R. (2020). Strengthening Students' Character Through Multimedia Learning In Primary Schools Education: Systematic LiteraturPrasetyo, G., Hidayatullah, M. F., Akhyar, M., Wiranto, \& Perdana, R. (2020). Strengthening Students' Character Through Multimedia Learning In . Humanities \& Social Sciences Reviews, 8(3), 268-277. https://doi.org/10.18510/hssr.2020.8328.

Pratiwi, I., Suartama, I. K., \& Tegeh, I. M. (2016). Pengembangan E-Learning dengan Model Prototype Berorientasi Model Pembelajaran Inquiry Siswa Kelas VII SMPN 2 Negara. Jurnal Edutech Undiksha, 4(2). https://doi.org/10.23887/jeu.v4i2.7615.

Puspitarini, Y. D., \& Hanif, M. (2019). Using Learning Media to Increase Learning Motivation in Elementary School. Anatolian Journal of Education, 4(2), 53-60. https: //doi.org/10.29333/aje.2019.426a.

Putra, R. W. P. (2021). Improving the Students' Motivation in Learning English through Google Meet during the Online Learning. English Learning Innovation, 2(1), 35-42. https://doi.org/10.22219/englie.v2i1.14605.

Rahayu, N. D., Zulherman, Z., \& Yatri, I. (2021). Animated Video Media Based on Adobe After Effects ( AEF ) Application: An Empirical Study for Elementary School Students. Journal of Physics: Conference Series, 1783(1), 012116. https://doi.org/10.1088/1742-6596/1783/1/012116.

Saripudin, E., Sari, I. J., \& Mukhtar, M. (2018). Using Macro Flash Animation Media on Motion Material to Improve Learning Achievement for Learning Science in Junior High School. Jurnal Penelitian Dan Pembelajaran IPA, 4(1), 68-75. https://doi.org/10.30870/jppi.v4i1.3316.

Satria, M. R., \& Fatmawati, A. P. (2021). Penyusunan Laporan Keuangan Perusahaan Menggunakan Aplikasi Spreadsheet (Pada Pd Beras Padaringan). Fair Value Jurnal Ilmiah Akuntansi Dan Keuangan, 3(2), 146-164. https://doi.org/10.32670/fairvalue.v3i2.146. 
Sert, N., \& Boynueğri, E. (2017). Digital technology use by the students and english teachers and selfdirected language learning. World Journal on Educational Technology: Current Issues, 9(1), 24. https: //doi.org/10.18844/wjet.v9i1.993.

Setyowati, A., Efendi, A., \& Basori, B. (2018). The Analysis of Reward Systems Implementation in Basic Network Course: Case Study of a Vocational School in Solo, Central Java. IJIE (Indonesian Journal of Informatics Education), 2(1), 57. https://doi.org/10.20961/ijie.v2i1.13198.

Silaban, R. A., \& Rizal, F. (2020). The Development of Program Logic Control (PLC) Trainer Media in Vocational High Schools. Journal of Education Research and Evaluation, 4(2), 121. https://doi.org/10.23887/jere.v4i2.24606.

Sudjimat, D. A., \& Luchyto. (2019). Effect Of Work-Based Learning Model On Students' Achievement Motivation. Jurnal Pendidikan Teknologi Dan Kejuruan, 25(2). https://doi.org/10.21831/jptk.v25i2.24416.

Sugiyono. (2013). Metode Penelitian Kuantitatif, Kualitatif dan R\&D. Bandung: Alfabeta.CV.

Sulindawati. (2021). Development Media Analysis in Financial Statements Learning Practices of Hospitality Entities Through Spreadsheet. https://doi.org/10.4108/eai.1-10-2020.2304926.

Tafonao, T. (2018). Peranan Media Pembelajaran Dalam Meningkatkan Minat Belajar Mahasiswa. Jurnal Komunikasi Pendidikan, 2(2), 1-13. https://doi.org/10.32585/jkp.v2i2.113.

Tafqihan, Z. (2011). Karakteristik Dan Pemilihan Media Pembelajaran Dalam E-Learning. Cendekia: Jurnal Kependidikan Dan Kemasyarakatan, 9(2), 141-154. https://doi.org/10.21154/cendekia.v9i2.871.

Undiksha. (2017). Pedoman Studi Program Sarjana dan Diploma Universitas Pendidikan Ganesha.

Widiana, I. W., \& Rendra, N. T. (2020). The Effectiveness of the Learning Model Oriented Towards the Dimensions of Knowledge and Cognitive Processes. Journal of Education Research and Evaluation, 4(4), 304. https://doi.org/10.23887/jere.v4i4.30041.

Wu, D., Wang, H., Huang, L., \& Wang, Y. (2021). Computer aided machining fixture design algorithm and software based on case learning for near-net-shaped jet engine blade. Journal of Manufacturing Processes, 69. https://doi.org/10.1016/j.jmapro.2021.07.057.

Yasdar, M., Djafar, S., Elihami, E., \& Faisal, F. (2019). Teaching Methods Used by Teachers in Primary Schools Inclusive. Edumaspul - Jurnal Pendidikan, 3(1), 38-47. https://doi.org/10.33487/edumaspul.v3i1.81. 